IJIET, e-ISSN 2548-8430, p-ISSN 2548-8422, Vol. 2, No. 2, July 2018

\title{
IJIET
}

International Journal of Indonesian Education and Teaching http://e-journal.usd.ac.id/index.php/IJIET

Sanata Dharma University, Yogyakarta, Indonesia

\section{LEARNING POETRY AS A STRATEGY TO DEVELOP STUDENTS' TEACHING SKILLS}

\author{
Maria Vincentia Eka Mulatsih \\ Sanata Dharma University \\ mv_ika@usd.ac.id \\ https://doi.org/10.24071/ijiet.v2i2.1092
}

Received 8 May 2018; revised 24 May 2018; accepted 21 June 2018

\begin{abstract}
Generally, learning poetry has some functions which deal with oral language development, student learning style expansion, world engagement with its content, and cultural awareness exploration. The fact is that not only does the Indonesian government try to put aside learning literature from all language study programs, but also some practitioners argue that there is no link between learning poetry and developing students' teaching skill in some teachers training departments. This article argues that learning poetry can be a medium to develop students' teaching skill in sharing the knowledge independently and creatively. Some practices that have been conducted in two poetry classes of English Language Education Program, Sanata Dharma University in 2017 are being discussed in relation to improve students' teaching skill as preliminary activities before having a micro teaching class. Additional data about students' response toward the practices are also shown. It was found that $82 \%$ students agreed that those practices developed students' teaching skill in sharing the knowledge that they obtained.
\end{abstract}

Keywords: learning poetry, practices, students' teaching skill

\section{Introduction}

The Indonesian Ministry of Research, Technology and Higher Education assigned all university study programs to set their name based on ministerial decree number 15 year 2017. One of the implications of the decree is the elimination of the word literature in study program name, e.g. Indonesian language and literature education study program changes into Indonesian language education study program. Some regulations in elementary and high schools were also made so that teachers would focus more on language learning and put aside literary works as learning materials. Those governmental effortsmay lead to a degradation era where young generation will not experience the benefits of reading literary works as human expression and thought. One of the benefits deals with knowing the different culture, religion, ethnic that makesstudents tolerate others' differences. Although the learning process of this sense oftolerance faces many obstacles as stated by Suparno (2017), we should not give up on teaching it. The real implementation of using literary genre for teaching and 
improving others' culture respect was done by Yektiningtyas and Modouw (2017). They infused Sentani culture in their English learning materials.

Folktales are chosen as learning materials for Elementary School students, malo for Junior High School students, the procedure to make kayi/ifa for Senior High School students. This infusion hopes that young generation is able to learn English as well as to acknowledge one of the cultural heritages of Papua. They can be strongly rooted in their culture and respect others' culture (p. 40). From that explanation above, the elimination of literary works as teaching materials is considered high risk.

Sanata Dharma as one of universities in Indonesia underlines the importance of studying literary works in learning language by doing some actions. First, this university will not eliminate the name of literature in its language study program (Pendidikan Bahasa dan Sastra Indonesia \& S2 Pendidikan Bahasa Sastra Indonesia). Second, some practices in relation to studying literature are still maintained. One of them is the learning poetry in English language education study program.

Relating to language acquisition, many experts claim that learning poetry has many benefits. Hadaway, Vardell, and Young. (2001) stated that learning poetry can develop student's oral language due to its regular practices in reciting several poems. Aydinoglu (2013) integrated learning poetry with vocabulary teaching. Students could enrich their vocabulary by having poems as the material. Hanauer (2001) said that by having poetry reading task, students realized the gap between their culture and the culture of second language of the poems in order to understand the possible meaning and uses of the words. It also proves that learning poetry has connection with cross cultural understanding. It explores students' cultural awareness. For the real teaching and learning activities, Richard (1988) proposed some teaching methods such as storytelling and role play. Those experts agree that learning poetry brings good benefits for students and it was practically done. It means that students' competence for their language acquisitioncan be gained from learning poetry.

Beside its' benefit for language acquisition, learning poetry gives positive effect to students too. Reid (1995) connected learning poetry with students' learning style expansion. Pullinger also reminds that as teachers, we should not forget to motivate students to learn value in discussing poems. Then, students mayrelate it with their experience and get better understanding about humanity. Their engagement with the world is one of the results of learning poetry (Pullinger: 2012). In the other words, students may improve their compassion and conscience from learning poetry. For pre service teachers, a study that was conducted by Dymocke and Hughes (2009) in UK and Canada helped them in gaining self- awareness of being a writer and future teachers of writing. By having wiki environment, future teachers collaborated to support their professional learning. InIndonesia, the growth of poetry is undeniable. We have at least "50 title of Indonesian children poems written by child poets" that were analyzed by Mulyono (2018, p. 228).

Knowing those benefits and its dynamic of learning poetry, the writer aims to show the connection between learning poetry and improving students teaching 
skill. This paper focuses more on the practices on teaching poetry for second language learners to improve their teaching skill. Besides, students' perspective toward the practices is provided too.

There are many definitions of teaching. Generally, teaching relates to a profession namely teacher who causes students to learn or to understand new things. Smith (2015) defines teaching as a specific action to help students to learn things. $\mathrm{He}$ also mentions that it relates to learning and sharing the belief in life. In line with Smith, Hirst (1975) states that teaching is intended for someone to learn something. Based on those definitions, there is a red line about teaching in the condition of learning. One of many ways for achieving the learning condition, which is clearly stated by Smith, is the activity of sharing. Adapting previous definitions, teaching in this article is the ability to share knowledge from one source (a future teacher) to audience (classmates) about poetry subject so that his or her classmates will learn and understand the material. Teaching skill that is intended to be improved is the ability of sharing knowledge about poetry.

There are four different learning styles based on Fleming's theory (2012). Those four styles relate to sensory modalities that students preferred, namely: aural, visual, read or write, and kinesthetic. Some students prefer to see, some others prefer to hear, some students like to read or write, and the rest - they like todo or practice it. This theory has a connection with Dale's theory. Dale cited by Dugan $(1955,244)$ also categories those four learning styles into six levels of remembering. He states that after two weeks, students generally remember $10 \%$ of the material that they read, $20 \%$ from all they heard, $30 \%$ the visual that they saw, $50 \%$ when they both heard and saw, $70 \%$ from what students said and wrote, and $90 \%$ when they really did that.

It is important that learning activities accommodate those students' four modalities and preserve the materials that they have learned. For accommodating students' four modalities, the activities which are done in the class vary from listening, speaking, reading, writing, watching and practicing. An effort to maximize the capacity of students' memory of the materials can be done by having a real implementation. Students need to do something so that they will remember more.

There are some activities to apply four modalities and maximize students' memory, namely: presentation, focus group discussion, role play, and gamification. Those are wrapped with developing students' autonomy. Students understand the goal of the lesson and find their own way to achieve the goal. In this case, students may choose the theme and the activity that they like for the final project based on their interest. Chickering and Gamson (1987) state that students' interest gives good impact for a better learning condition.

\section{Method}

Since the focuses of this paper are two, namely practices in Poetry classes to improve students' teaching skill and students' perspective toward the practices, the data are classified into two groups. The first data related to practices as a connection between Poetry material and students' teaching skill were gathered from observation for one semester (February-June 2017) in two Poetry classes of 
ELESP Sanata Dharma. The results of the observation were noted in the note book. The second data in relation with students' perspective toward the practices were obtained from spreading a questionnaire to all students who have attended those two Poetry classes. The type of questionnaire was closed one with Likert scale from one to four ( $1=$ totally disagree, $2=$ disagree, $3=$ agree, and $4=$ totally agree). The distribution of questionnaire was done in the last meeting after all learning activities have been finished. There were 68 students who participated. First class was E class and it consisted of 33 students. Second class was B class and it consisted of 36 students. One participant was absent in the last meeting. These two classes were chosen out of five classes due to the fact that only those classes which implemented specific practices that have been stated in previous chapter. There was not any clear distinction between those two classes. The students got same treatments in the beginning and decided the practices to connectbetween poetry material and teaching skill.

The presentation of the first data about the practices is done descriptively. The second data are analyzed by calculating the scale to find the mean and these data are presented quantitatively.

\section{Findings and Discussion}

\section{Learning poetry material to build the expertise in teaching}

In the first meeting, lecturer delivered the goals of the course that dealt with poetry, its elements, appreciation and teaching skill, then asked students several possible activities to achieve the goals together. There were some discussions about students' interest \& idea and a debate among students too. Students decided the activities and made commitment based on class decision together with the lecturer. In this phase, students realize that being a teacher needs to be responsiblefor the decision that they make. Not only did student deal with the freedom of choosing the activity to achieve the goal of the subject, but also they dealt with thefreedom of choosing the poem that they liked or knew. They independently chose their poem as the material of their analysis. For those who were not familiar with poetry, they themselves began to explore and look for a poem that was easy for them. As future teachers, students learn to have their own independency to look for the appropriate materials to be taught.

In the second up to seventh meetings, there were students' presentations that were wrapped with a focus group discussion. Students learned independently about material that would be presented, discussed in their group about the material and its job distribution, presented their findings about the elements of poetry and its analysis toward their own chosen poem, and had some feedbacks and questionsfrom other groups in the class. Lecturer added more information, proposed several thought provoking questions and concluded the result of the discussion. Through those activities, students learned to collaborate with partners to obtain their individual goal as a preliminary experience of networking, share the knowledge that they studied before to their friends in the class, make sure that their friends understand the material by having a whole class exercise and answer friends' question in relation with the material that they have delivered. Focus group discussion is the medium to help students discuss the material in the class without 
lecturer's interference. Presentation in focus group discussion allows students to learn that being a teacher needs to read, learn and understand the materials before they present them. Students also realize the need of participants' feedback to make sure that the materials is well received or understood. Focus group discussion was recognized as a different form of peer feedback. Teacher needs to have a suggestion from colleague in the implementation of certain method and thechoice of materials.

Throughout the three meetings before the final test, students started to discuss the plans of their previous decision that they have made in the first meeting in the group. Students of E class decided to have a poetry performance. This class was divided into two big groups based on students' choice. Those groups created their own poems, recited those poems, and arranged its' musical performance. Their chosen themes were love and nationality. Students of B class were divided into six groups. Their focus was to teach a poem with an interesting way. Some groups had a talk show, two groups had a drama of their chosen poems and others had a pantomime. The lesson that they got in this project was that teachers needed to develop creativity to deliver the materials.

Presentation, forum group discussion, students' choice for their final project accommodated four styles of learning, namely aural, visual, read or write, and kinesthetic. Before conducting presentation, students tried to look for specific information with different ways, for example reading some websites, watching YouTube videos. After they got the information, they created a power point. Those activities as the preliminary before the presentation made students activate the aural, visual and read as learning styles. For kinesthetic learning style, final project accommodated it by having poetry performance, talk show, drama or pantomime. The most important thing was that students implemented teaching poetry materials in the class for real and it led them to memorize more for the materials that they have learned. Students practiced directly, taught other friends, had discussion and did their choice for their final project. Those activities helped them to improve their teaching skill in the way of sharing the knowledge that they got to other students. Teaching cannot always be defined as a formal process inthe class where students and teacher exist. Teaching is a way to make others understand the knowledge and to achieve the goal together by supporting each other.

It was interesting when a group consisted of three members presented their poetry materials on how to implement sociological approach first by showing a video of a song entitled "Imagine" by The Beatles without having any slide to share the knowledge. They asked students to sing together in the beginning and gave some questions to their friends about the connection between a song and a poem. After the discussion, they shared the background of the song based on the reality that happened at that time that was the world war. Then, they also asked about the lyrics of the song as a proof of the poet's feeling toward the war. There were other students appreciated their presentation by saying directly that their presentation was interesting and two students asked some questions to the group. In this process, students' creativity to develop poetry material and to deliver it were stimulated. For visual learners, they watched the video. Students who were 
good at listening, they also listened to the song. Moreover, they also sang the song as a real implementation of their kinesthetic. Those activities dealt with four different kinds of learners as mentioned before. The six levels of remembering were also accomplished because students have read the lyrics, listened the song, watched the video, sang it, and asked some questions. For students who presented the material, before teaching, they read and understood the concept of sociological approach first, tried to find the appropriate song and listened it, discussed with other members in the group and finally they shared it as a real implementation. It was the example of $10 \%$ up to $90 \%$ Cole's cone of learning.

To measure their understanding, there were a midterm test two and quizzes. All the questions were taken from the materials that have been presented. Basedon the result taken from those tests, students began to understand some approaches to analyze a poem and had their original interpretation toward their chosen poem. They also presented the material well and committed for completing project in their group. During focus group discussion, they wereactively asking questions. The activities that have been done in those Poetry classes refer to students' competence for understanding the materials and for having a practice in sharing the materials as an element of teaching. Those activities involved both students' learning autonomy and students' creativity

\section{Students' perspective toward the practices}

There were two kinds of student's response toward the practices. The first was the written form taken from SIA Dosen (Lecturers' academic information system). The second was the statistic result of the questionnaire distribution. These were some students' comments on SIA:

No Students' feedback in Bahasa Indonesia Translation

\footnotetext{
$1 \quad$ Aktivitas seperti presentasi kelompok juga membantu mahasiswa untuk belajar secara kelompok dan dapat memahami materi dengan baik. Dosen juga selalu memberikan feedback dan merangkum apa yang telah dipelajari pada saat itu.

2 Strategi pembelajaran sudah sangat baik, mahasiswa dapat mengembangkan makna bahkan menganilisis puisi dengan kreatif.

3 Ujian akhirnya asik, nggak kaya mata kuliah lain. Dosen selalu menanyakan pendapat mahasiswanya ketika ingin menentukan pilihan di kelas.

$4 \quad$-Beliau memberikan pilihan kepada mahasiswa untuk menentukan final project. Beliau sangat mengapresiasi apa yang telah dikerjakan oleh mahasiswanya. -

\author{
Activity such as group presentation also \\ helped students to learn and understand the \\ materials well. Lecturer also gave feedback \\ and summed up all materials that has been \\ learnt at that time. \\ Learning strategy was already very good, \\ students could develop meaning even analyze \\ poems creatively. \\ Fun final test, it was not like other subjects. \\ Lecturer always asked students' opinion when \\ she wanted to decide the choice of the class. \\ She gave some choices to students to decide \\ final project. She really appreciated what had \\ been done by her students.
}


Based on the data above, students' freedom for choosing the materials \& the project in achieving the goal of the course was well appreciated. It was the main key to connect some poetry materials with the improvement of teaching skill in two Poetry classes.

Before having the data analysis of students' perspective toward the practices for improving their teaching skill, most students agreed that the concept of teaching had a close relation with sharing the knowledge and various ways to deliver it. It was shown in the figure below:

Only three students did not agree that the concept of teaching was about sharing the knowledge and none of students totally disagreed. There was not any student who disagreed or totally disagreed that teaching related to various ways of delivering and sharing the materials. In detail, 32 students agreed and 33 students strongly agreed that teaching concept was about sharing and the number increased to 26 students who agreed

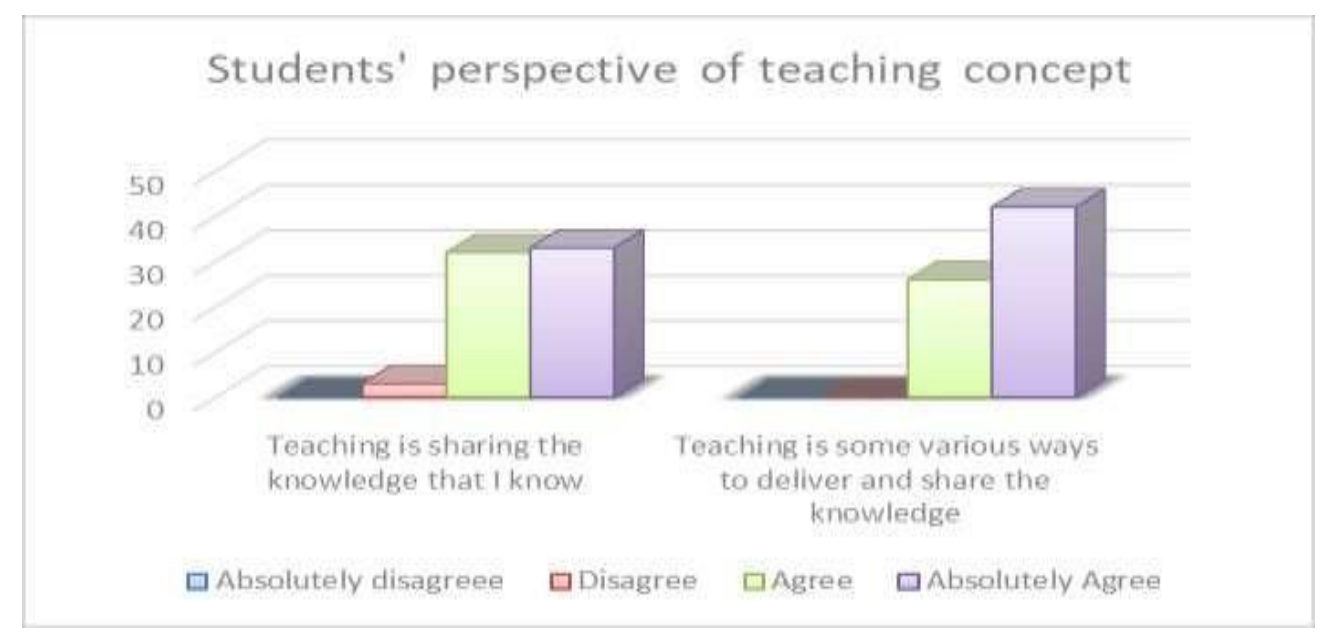

and 42 students who totally agreed that teaching related with various ways of delivering and sharing the knowledge. Those findings showed that most students had a concept that teaching had a close relation with sharing activity.

There were some activities done based on students' choices namely presentation, projects and poetry performance. The first part dealt with presentation, the second and the third parts were some projects and the last was poetry performance.

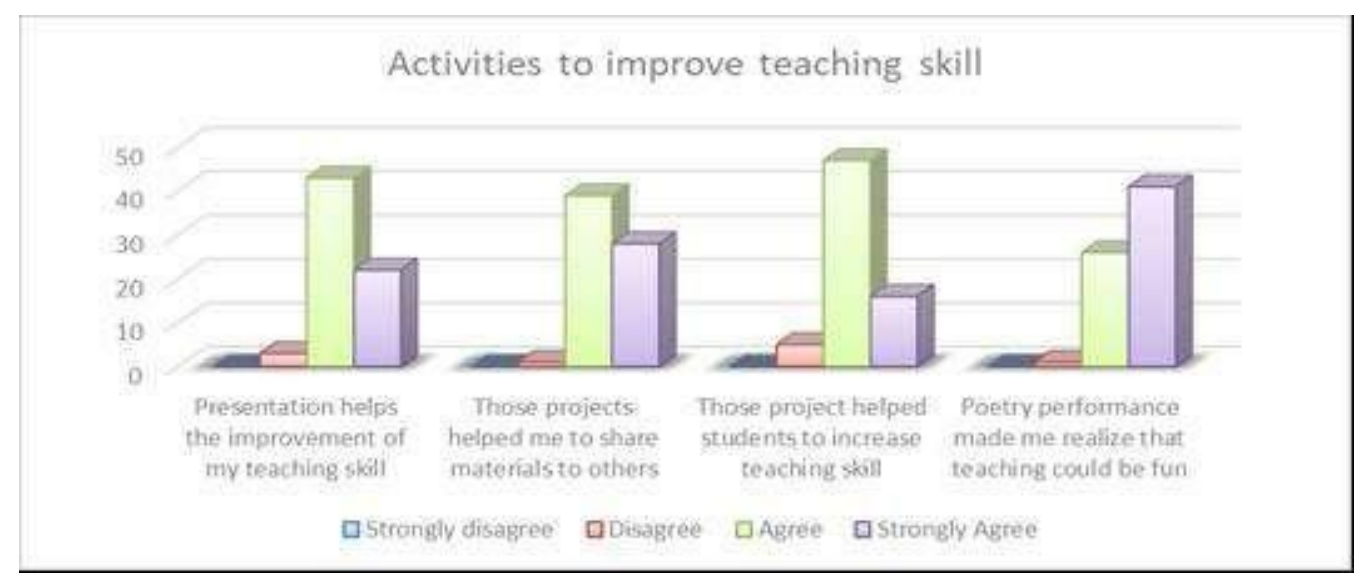


For presentation activity, 43 students agreed and 28 students strongly agreed that presentation helped their improvement of teaching skill; only three students who disagreed. Its' mean was 3.28. Meanwhile, the mean of some projects reached to 3.38 for sharing materials improvement and 3.16 for students' teaching skill improvement. The last activity that was poetry performance had the highest mean of 3.59. From the result of the questionnaire, all the mean reached to three as the level of agreement. It indicated that students' felt those three activities namely presentation, projects and poetry performances had already helped them to develop their teaching skill. The materials were closely related with teaching as the theme of both Poetry classes.

From the data above, students agreed that those activities could be the means to develop their teaching skill and furthermore to start learning their teaching expertise. There were two important aspects that they realized to be had. The first was their independency as autonomous learners when they had to master the materials well before sharing. The second was their own creativity to deliver the materials so other friends would understand the material because their interesting way to share the knowledge mattered. Other teaching expertise that could be gained dealt with students' awareness of collaboration in their team to achieve the goal together. It symbolized the relation that needed to be built among teachers in a school. Briefly, their teaching expertise began with their independency of learning, creativity of sharing and maintaining good relation with other members in their group.

\section{Conclusion}

Literary works, in this case poems, are able to be used as materials to develop many skills of those who study them. Based on its nature as dynamic materials, poetry can be used not only for improving students' oral skill but also for improving students' teaching skill especially for sharing the material. To sum up, there are some important practices that need to be done: 1) giving a freedom for choosing a poem that a student really likes, 2) having a commitment to achievethe goal of the course together by having an open discussion, 3) involving independency and creativity of students, 4) accommodating four styles of students' learning. In a nutshell, lecturer can have some literary works including poetry as a material for future teachers due to its benefits, namely: improving teaching skills through its real practices, gaining students' competence for its language acquisition, exploring students' conscience and compassion. Learning literary works has a lot of functions for students' life, even for formal one that isto develop teaching skill for students of education program.

\section{References}

Aydinoglu, N. (2013). Integration of poetry with vocabulary teaching. Mediterranean Journal of Educational Research, 14(a), 274-284.

Chickering, A. W., \& Gamson, Z. F. (1987). Seven principles for good practice in undergraduate education. AAHE bulletin, 3, 7.

Christison, M. A., \& Bassano, S. (1995). Expanding student learning styles through poetry. Learning styles in the ESL/EFL classroom, 96-107. 
Dugan, J. E. (1955). Audio-visual methods in teaching. In Edgar Dale (Ed.). New York. The Dryden Press.

Dymoke, S., \& Hughes, J. (2009). Using a poetry wiki: How can the medium support pre-service teachers of English in their professional learning about writing poetry and teaching poetry writing in a digital age?. English Teaching, $8(3), 91$.

Fleming, N. (2012). Teaching and learning styles: VARK strategies. Springfield: Neil D Fleming.

Hadaway, N. L., Vardell, S. M., \& Young, T. A. (2001). Scaffolding oral language development through poetry for students learning English. The Reading Teacher, 54(8), 796-806.

Hanauer, D. I. (2001). The task of poetry reading and second language learning. Applied linguistics, 22(3), 295-323.

Hirst, P. (1975). What is teaching? In R. S. Peters (ed.) The Philosophy of Education. London: Routledge and Kegan Paul.

Pullinger, D. (2012). In living memory: The dying art of learning poetry and a case for revival. Changing English, 19(4), 383-393.

Mulyono, T. (2018). The linguistic features of Indonesian children poetry. International Journal of Humanity Studies (IJHS), 1(2), 228-236. Retrieved from http://e-journal.usd.ac.id/index.php/IJHS/article/view/883

Richard-Amato, P. A. (1988). Making It Happen: Interaction in the Second Language Classroom, From Theory to Practice. Longman Inc., 95 Church St., White Plains, NY 10601-1505

Smith, M. K. (2015). What is education? A definition and discussion. The encyclopedia of informal education. [http://infed.org/mobi/what-is-educationa-definition-and-discussion/. Retrieved: July $\left.20^{\text {th }}, 2017\right]$.

Suparno, P. (2017). Pluralistic and Multicultural Education in the Indonesian Schools. International Journal of Indonesian Education and Teaching (IJIET),

$$
\text { 1(1), 9-15. Retrieved from http://e- }
$$
journal.usd.ac.id/index.php/IJIET/article/view/328

Yektiningtyas, W., \& Modouw, J. (2017). Infusing culture in English learning: an attempt to preserve cultural heritages in Jayapura municipality, Papua. LLT Journal: A Journal on Language and Language Teaching, 20(1), 40-48. Retrieved from http://e-journal.usd.ac.id/index.php/LLT/article/view/506 